\title{
FOREIGN BODIES IN EAR, NOSE, THROAT AND ESOPHAGUS HANDLED IN OUR CLINIC DURING LAST 10 YEARS
}

By

TAKashi MATSUNAGA, TAKEO SATO, YASUYUKi YAMADA and Hiroyasu KAWAMOTO

\section{From the Department of Oto-Rhino-Laryngology, Osaka University Medical School (Director: Prof. Toshi Naito, M.D.)}

Statistical observation on the cases of foreign bodies handled in our clinic during the period from 1956 through 1965 was performed.

The results were as follows.

1. 1,043 cases (approximately $1 \%$ ) out of 108,760 patients treated in our ear, nose and throat clinic during last 10 years, were recognized as the foreign bodies.

2. The locations of the foreign bodies were as follows: 507 cases in esophagus (50\% of all foreign bodies), 177 cases in pharynx (17\%), 170 cases in gastrointestinal tracts $(16 \%), 63$ cases in larynx, trachea and bronchus $(6 \%), 87$ cases in ear $(8 \%), 41$ cases in nose $(4 \%)$ and 2 cases in maxillary sinus.

3, More than $50 \%$ of the foreign bodies were found in infants and were found to be coins in esophagus.

It is important to discuss about the cases of coins in esophagus as well as beans in bronchus of the infants.

4. 365 cases $(72 \%)$ of 507 cases in esophagus were coins which were lodged at the entrance of esophagus. Fish bones, artificial dentures and pieces of meat were seen in the second strictures as much as in the first strictures.

i24 (90\%) of 139 foreign bodies found in mesopharynx were fish bones and more than $50 \%$ of them were found within the palatine tonsil.

Foreign bodies in bronchus were seen in 48 cases, which were almost lodged at the area of carina.

Insects were most common among the foreign bodies of ear canals and often cause otitis media.

5. The removal of foreign bodies in about $75 \%$ of total cases was performed by means of Endoscopy. Foreign bodies were removed via the external esophagotomy approach in 5 cases and via the tracheotomy approach in 13 cases.

6. The complications of foreign bodies in esophagus were periesophageal abscess in 6 cases and in death in 2 cases. Especially in infant, there were 11 cases diagnosed as other respiratory diseases than foreign bodies by the pediatrist and 3 cases suffocated to death. The foreign bodies in these cases were found by the bronchoesophagologist.

7. The authors reported the statistics of foreign bodies, treated in our clinic during the period of 1936 1965.

\section{我教室 10 年間の異物 症統計}

$$
\begin{aligned}
& \text { 大阪大学医学部耳與咽堠科学教室 (主任: 内藤售教授) }
\end{aligned}
$$

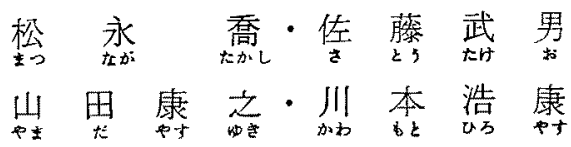

当教室における昭和 31 年上り昭和 40 年まで 10 年間 の異物泟の統計的観察を試みたので報告する.

\section{A) 総 論}

昭和 31 年上り昭和 40 年をでの 10 年間の当科外来新

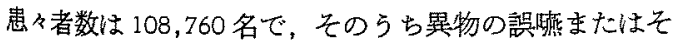
の疑いで来院せるものは1,414 例であつた。らち体肉に
異物を確諗しえたものは1,043例（1\%)で，以下この 1 , 034 例についてまず総括的に報告与る (第 1 表).

1. 年度別

第 1,2 表に示吉如く，年間約 100 例の買物症があり， 昭和 37 年までは年間約 80 例ですつたものが，昭和 38 年以降最近の3 年間は年間約 150 例となり，異物症の增 
第 1 表 年度別異物症例数

\begin{tabular}{|c|c|c|c|}
\hline 年度】異物证 & 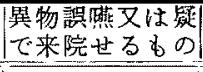 & $\begin{array}{l}\text { 体内異物 } \\
\text { 確 諗 例 }\end{array}$ & $\begin{array}{l}\text { 体内䔬物 } \\
\text { 不碓認例 } \\
\end{array}$ \\
\hline 昭和 31 年 & 132 例 & 103 & 29 \\
\hline 32 & 96 & 82 & 14 \\
\hline 33 & 120 & 92 & 28 \\
\hline 34 & 89 & 78 & 11 \\
\hline 35 & 114 & 88 & 26 \\
\hline 36 & 87 & 64 & 23 \\
\hline 37 & 106 & 81 & 25 \\
\hline 38 & 195 & 139 & 56 \\
\hline 39 & 232 & 153 & 79 \\
\hline 40 & 243 & 163 & 80 \\
\hline 計 & 1414 & 1043 & 371 \\
\hline
\end{tabular}

第 2 表 年度別各帯留部位異物症数

\begin{tabular}{|c|c|c|c|c|c|c|c|c|c|c|c|}
\hline 入漫留部位 & $\begin{array}{l}\text { 食 } \\
\text { 道 }\end{array}$ & $\begin{array}{l}\text { 胃 } \\
\text { 晹 }\end{array}$ & $\begin{array}{l}\text { 上 } \\
\text { 咽 } \\
\text { 頭 }\end{array}$ & $\begin{array}{l}\text { 中 } \\
\text { 咽 } \\
\text { 頭 }\end{array}$ & $\begin{array}{l}\text { 下 } \\
\text { 咽 } \\
\text { 頭 }\end{array}$ & 陪 & $\begin{array}{l}\text { 気 } \\
\text { 管 }\end{array}$ & 耳 & 番 & $\begin{array}{l}\text { 上 } \\
\text { 䫌 }\end{array}$ & 棓" \\
\hline 昭和31年 & 46 & 18 & $\mathrm{O}$ & 17 & 0 & 2 & 7 & 11 & 2 & $d_{1}^{\prime}$ & 103 \\
\hline 32 & 48 & 11 & 0 & 6 & 3 & 2 & 3 & 5 & 4 & of & 82 \\
\hline 33 & 42 & 14 & o & 14 & 3 & 2 & 6 & 10 & 2 & o & 92 \\
\hline 34 & 44 & 14 & 0 & 2 & 1 & 2 & 4 & 10 & 1 & o & 78 \\
\hline 35 & 34 & 19 & 1 & 21 & 2 & 1 & 3 & 5 & 2 & o & 88 \\
\hline 36 & 37 & 4 & $0_{0}$ & 8 & 3 & 3 & 2 & 5 & 2 & 0 & 64 \\
\hline 37 & 38 & 9 & 0 & 7 & 9 & 0 & 4 & 10 & 3 & 1 & 81 \\
\hline 38 & 67 & 21 & 0 & 25 & 4 & 1 & 8 & 7 & 5 & 1 & 139 \\
\hline 39 & 72 & 33 & 1 & 20 & 5 & 2 & 3 & 11 & 7 & o & 153 \\
\hline 40 & 79 & 27 & 0 & 18 & 7 & 0 & 8 & 13 & 13 & o & 163 \\
\hline की & & & & & 37 & 15 & 48 & 87 & 41 & 2 & 1043 \\
\hline
\end{tabular}

第 3 表 年度別異物の種類（全）

\begin{tabular}{|c|c|c|c|c|c|c|c|c|c|c|c|c|c|}
\hline 年 & 男 & 女 & $\begin{array}{l}\text { 貨 } \\
\text { 幣 }\end{array}$ & $\begin{array}{l}\text { 針 } \\
E^{\circ} \\
\text { V }\end{array}$ & $\begin{array}{l}\text { 鎬 } \\
⿱ 亠 \\
\forall \\
\forall\end{array}$ & $\begin{array}{l}\text { 魚 } \\
\text { 骨 } \\
\text { 片 }\end{array}$ & $\begin{array}{l}\text { 義 } \\
\text { 歯 }\end{array}$ & $\begin{array}{l}\text { 獣片 } \\
\text { 肉類 }\end{array}$ & $\begin{array}{l}\text { 豆 } \\
\text { 類 }\end{array}$ & $\begin{array}{l}\text { その } \\
\text { の食 } \\
\text { 地塊 }\end{array}$ & $\begin{array}{l}\text { 出ち } \\
\text { bや }\end{array}$ & $\begin{array}{l}z \\
\text { 号 } \\
\text { 他 }\end{array}$ & 計 \\
\hline 昭和 31 年 & 57 & 46 & 37 & 8 & 1 & 22 & 3 & 5 & 2 & 2 & 5 & 18 & 103 \\
\hline 32 & 50 & 32 & 36 & 6 & 2 & 11 & 3 & 3 & 0 & 2 & 3 & 16 & 82 \\
\hline 33 & 56 & 36 & 23 & 11 & 3 & 24 & 3 & 1 & 5 & 1 & 7 & 14 & 92 \\
\hline 34 & 50 & 28 & 25 & 6 & 2 & 9 & 6 & 4 & 2 & 4 & 5 & 15 & 78 \\
\hline 35 & 56 & 32 & 32 & 6 & 5 & 25 & 4 & 0 & 1 & 2 & 2 & 11 & 88 \\
\hline 36 & 30 & 34 & 19 & 5 & 0 & 22 & 0 & 3 & 2 & 2 & 2 & 9 & 64 \\
\hline 37 & 51 & 30 & 30 & 4 & 5 & 12 & 4 & 2 & 0 & 2 & 5 & 17 & 81 \\
\hline 38 & 74 & 65 & 55 & 12 & 5 & 28 & 8 & 4 & 4 & 0 & 5 & 18 & 139 \\
\hline 39 & 83 & 70 & 59 & 19 & 4 & 22 & 10 & 6 & 5 & 3 & 8 & 17 & 153 \\
\hline 40 & 96 & 67 & 56 & 11 & 6 & 29 & 7 & 7 & 5 & 5 & 16 & 21 & 163 \\
\hline 棓 & 603 & 440 & 372 & 88 & 33 & 204 & 48 & 35 & 26 & 23 & 58 & 156 & 1043 \\
\hline
\end{tabular}

加している傾向を示している，また同じ頃より異物症の らたがいで当科受䛦するるのが多くなつた，その疑いで 来院せるもののらら約 $30 \%$ が，体内に異物を認めなか つた，部位別では，食道胃腸異物が他のものに比して增 加し, 食道異物は年間異物症総数の約半数を占め, 最近 3 年間子小年間約 75 例亡なつている。胃腸異物は年間約 17 例，咽頭異物は年間約 15 例で中咽頭が殆んどであ る。㬋頭気筞異物は年間約 6,7 例，耳扰よび鼻異物は年 間夫々約 10 および 5 例前後となつて特に增減をみない。 稀な異物として上哣翼物 2 例，上咽頭累物1例を認め る、異物の種類としては第 3 表の加く，琟的に貨幣が 多く、ついで魚骨片、針ピン等が多い、また義柬, 玩具
（異物としてはその部分品，破片等が多い) b多くみら れる。份昭和 36 年は第 2 室戸台風で9,10月外来診察休 診で徙つて異物症も一番少くなつている.

2. 年令・性別

年令別異物症の分布は第 1 図第 4 表の如くで5才゙で の乳奻羿異物症の占める割合が約 $50 \%$ 以上であり，重 大な社会問題となつている。以下 20 才までは減少し， 20 才代でまた增加し，一つの peak を示し，以下各年 代層共大体平沟している，翼物の種類との関係では貨幣 異物は 5 才むでが压倒的多数を占め，豆類坃具類もこの 年代が殆んどである。ここに小見異物症の今後に残され た問題点がある。最近若い年代に義歯異物が多くなつて 
第 4 表 年令別異物の種類（全）

\begin{tabular}{|c|c|c|c|c|c|c|c|c|c|c|c|c|c|}
\hline 胙 & 男 & 女 & 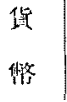 & $\begin{array}{l}\text { 針 } \\
ヒ^{\circ} \\
y\end{array}$ & $\begin{array}{l}\text { 釷 } \\
⿱ 亠 幺 \\
\dot{*}\end{array}$ & $\begin{array}{l}\text { 魚 } \\
\text { 兴 } \\
\text { 年 }\end{array}$ & $\begin{array}{l}\text { 義 } \\
\text { 露 }\end{array}$ & $\begin{array}{l}\text { 㯒片 } \\
\text { 闪類 }\end{array}$ & $\begin{array}{l}\text { 豆 } \\
\text { 題 }\end{array}$ & $\begin{array}{l}\text { その } \\
\text { 食 } \\
\text { 他塊 }\end{array}$ & $\begin{array}{l}f b \\
b p\end{array}$ & $\begin{array}{l}\text { 艺 } \\
\text { क } \\
\text { 他 }\end{array}$ & 訣 \\
\hline $0 \sim 5 t$ & 304 & 215 & 319 & 35 & 6 & 24 & 0 & 2 & 18 & 9 & 44 & 62 & 519 \\
\hline $6 \sim 9$ & 62 & 30 & 44 & 9 & 2 & 4 & 0 & 0 & 4 & 0 & 11 & 18 & 92 \\
\hline $10 \sim 15$ & 17 & 7 & 2 & 5 & 3 & 6 & 0 & 0 & 1 & 1 & 2 & 4 & 24 \\
\hline $16 \sim 19$ & 33 & 18 & 5 & 11 & 4 & 16 & 2 & 1 & 0 & 2 & 1 & 9 & 51 \\
\hline $20 \sim 29$ & 65 & 57 & 2 & 17 & 2 & 52 & 7 & 4 & 1 & 4 & 0 & 33 & 122 \\
\hline $30 \sim 39$ & 42 & 28 & 0 & 6 & 4 & 35 & 11 & 1 & 0 & 1 & 0 & 12 & 70 \\
\hline $40 \sim 49$ & 30 & 23 & 0 & 1 & 2 & 24 & 12 & 4 & 1 & 0 & 0 & 9 & 53 \\
\hline $50 \sim 59$ & 27 & 34 & 0 & 3 & 6 & 23 & 8 & 10 & I & 3 & 0 & 7 & 61 \\
\hline 60 以上 & 23 & 28 & 0 & 1 & 4 & 20 & 8 & 13 & 0 & 3 & 0 & 2 & 51 \\
\hline 計 & 603 & 440 & 372 & 88 & 33 & 204 & 48 & 35 & 26 & 23 & 58 & 156 & 1043 \\
\hline
\end{tabular}

第 1 図 年命別異物症

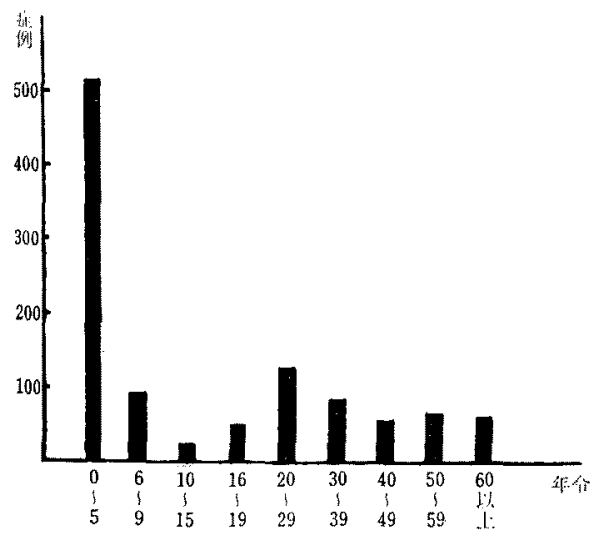

いる．魚骨片異物は中年層に多い，男女別では小児期， 青年期は男性に多く，50，60才と老年期になる之女性の 方が多くなる碩向がある．特に食道暴物は50,60才代で 山性飞多く，同年代の男性飞江胃腸異物が多い。また 老年期になると獣肉片類を゙じ方食塊の食道異物も比較 的多小。

3. 滞留部位別の比率

第 2,5，6 表に見る如く異物滞留部位により部位を分 けると食道異物が約 50\%，㸶頭異物，胃腸異物が $20 \%$ 弱，気管啹頭異物は6\%となつている，食道異物 507 例 中70\%以上が第一狭窄部以㴖留を諗めている。 その主 なるのは貨幣異物で 304 例中 250 例をでが第一狭窄部に
介在している，魚骨片，義困，獣肉片類等は第一及び第 二狭窄部にほ注同程度に認められる，中咽頚異物では口 盖扁桃部が $50 \%$ と最も多く，末た中㸶頭異物 138 例中 124 例すなから $90 \%$ までが第骨片であつた事忏特記す べき事である。気管では主気管，分岐部に多く，左在気 管支は同程度であり，異物の種類孔針，ピン、釗，ネジ 等尖鋭金属異物が多いが，大豆，ピーナッ，ソラマ风等 豆類も多い，下咽頭では梨子状简に多く認められる.

\section{4. 摘出方法}

食道異物 507 例中 396 例 78\% が食道直達鏡下儿晎物 摘出除去されている，直達鏡検查操作中胃内に落下した すのが96 例 (18\%) K見られる。この中には検查手技 の未熟に上るものも含まれるが術中嘔吐をくり返し㭘査 を一畤中止し 食道直達鏡再插入時，食道供異物なく $\mathrm{X}$

第 5 表 罢物の㳏留部位分類

\begin{tabular}{|c|c|c|c|}
\hline \multicolumn{2}{|c|}{ 筑留部位 } & 例 & 数 \\
\hline 食 & 道 & 507 例 & $(49 \%)$ \\
\hline 运 & 诨 & 177 & $(17 \%)$ \\
\hline 婯 & 魵 & 170 & $(16 \%)$ \\
\hline & 頭 & 63 & $(6 \%)$ \\
\hline & & 87 & $(8 \%)$ \\
\hline & & 41 & $(4 \%)$ \\
\hline 上 & 碩 & 2 & \\
\hline & & 1,043 & \\
\hline
\end{tabular}


第 6 表 各㣴留部位別異物症数

\begin{tabular}{|c|c|c|c|c|c|c|c|c|c|c|}
\hline \multicolumn{2}{|c|}{ 買物㴖留部位 } & 例 数 & 小計 & 貨 俑 & 魚骨片 & 㼁 歯 & 獣肉片類 & 針ピン & 釘ネシ & 豆 類 \\
\hline $\begin{array}{l}\text { 食 } \\
\text { 道 }\end{array}$ & 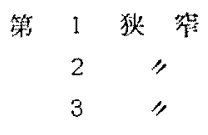 & $\left.\begin{array}{cc}365 & (72 \%) \\
113 & (22 \%) \\
29 & \end{array}\right\}$ & 507 & $\begin{array}{r}250 \\
28 \\
16\end{array}$ & $\begin{array}{r}29 \\
26 \\
1\end{array}$ & $\begin{array}{r}16 \\
19 \\
4\end{array}$ & $\begin{array}{r}17 \\
17 \\
1\end{array}$ & $\begin{array}{r}11 \\
5\end{array}$ & 1 & \\
\hline $\begin{array}{l}\text { 中 } \\
\text { 明 } \\
\text { 潩 }\end{array}$ & 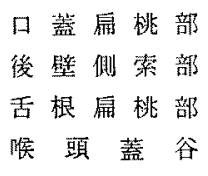 & $\left.\begin{array}{cc}73 & (53 \%) \\
6 & \\
25 & (18 \%) \\
34 & (24 \%)\end{array}\right\}$ & 138 & & $\begin{array}{r}68 \\
5 \\
22 \\
29\end{array}$ & & & $\begin{array}{l}2 \\
3\end{array}$ & $\begin{array}{l}1 \\
2 \\
2\end{array}$ & \\
\hline 気 & $\begin{array}{llll}\text { 右 気管 } & \text { 支 } \\
\text { 左 } & & \\
\text { 気 } & & \text { 管 } \\
\text { 分 } & & \text { 岐 } & \text { 部 }\end{array}$ & $\left.\begin{array}{ll}12 & (26 \%) \\
11 & (21 \%) \\
16 & (34 \%) \\
9 & \end{array}\right\}$ & 48 & & 1 & & & $\begin{array}{l}3 \\
8 \\
4 \\
1\end{array}$ & 2 & $\begin{array}{l}3 \\
3 \\
4 \\
2\end{array}$ \\
\hline $\begin{array}{l}\text { 下 } \\
\text { 咽 } \\
\text { 影 }\end{array}$ & 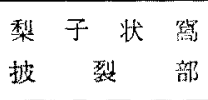 & $\left.\begin{array}{ll}27 & (73 \%) \\
10 & (27 \%)\end{array}\right\}$ & 37 & & $\begin{array}{r}15 \\
5\end{array}$ & 2 & & $\begin{array}{l}3 \\
1\end{array}$ & $\begin{array}{l}3 \\
0\end{array}$ & \\
\hline $\begin{array}{l}\text { 喉 } \\
\text { 頭 }\end{array}$ & $\begin{array}{ccc}\text { 声 } & \text { 朋下 } & \text { 膑 } \\
\text { 声 } & \text { 門 } & \text { 裂 }\end{array}$ & & 15 & & 4 & & & 1 & 1 & 1 \\
\hline 胃腸 & 閣 & & 170 & 78 & & 8 & & 44 & 19 & \\
\hline & 計 & & & 372 & 204 & 48 & 35 & 88 & 33 & 13 \\
\hline
\end{tabular}

\section{第 7 表 䨳物摘出法}

$\begin{array}{cr}\text { A. 食道買物 } & 507 \text { 例 } \\ \text { 1. 直達鏡にて } & 396 \\ \text { 2. 外切開法 } & 5 \\ \text { 3. 胃内落下 } & 96 \\ \text { 4. 吖 出 } & 10\end{array}$

B. 気管，㬋顛紫物 63 例

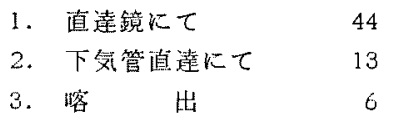

線透視下に胃内罢物と確諗したものが多い，また食道外 切開法を行つたものが 5 例あり，義霆 4 例，魚骨(口 チ) 1 例である，外切開例の詳細は別に報告する、気管

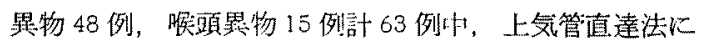
よつたものが 44 例 70\% で，下気管直迹法すなわら気管 切開法によつたものが13例20\%である(第7表).

$$
\text { 5. 合 併 症 }
$$

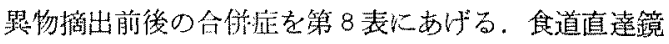

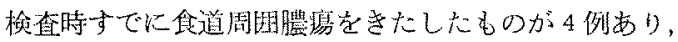

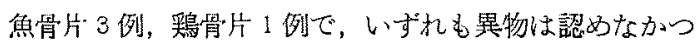

第 8 表 異物摘出前䥻の合淤症

A）食道異物症

\begin{tabular}{l}
\hline \\
\hline \hline
\end{tabular}

B）気管喉頭異物症

\begin{tabular}{|c|c|c|c|c|c|c|c|c|c|}
\hline & & & & & 摘 出 & 前 & 摘 & 出 & 後 \\
\hline 気 & 管 & & 支 & 炎 & 4 & 例 & & & \\
\hline 気 & 管 & 支 & 湍 & 息 & 4 & 例 & & & \\
\hline 脯i & & & & 炎 & 2 & 例 & & & \\
\hline 鰽 & & 武i & & 䐈 & 1 & 例 & & & \\
\hline 気 & & & & 购 & & & & 1 & 例 \\
\hline 曂苝 & T & 性 & 䏫 & 炎 & & & & 1 & 例 \\
\hline 死 & & & & 亡 & 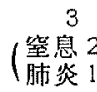 & $\begin{array}{l}\text { 例 } \\
\text { 例 } \\
\text { 例 }\end{array}$ & & & \\
\hline
\end{tabular}


たが，異物による自然化膿例である，食道直達鏡操作

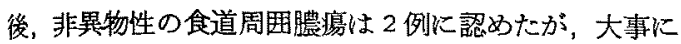
いたらず治癒している，すなわち42才男子食道第一狭窄

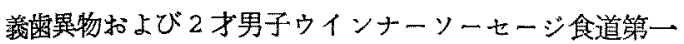
狭窄異物の 2 例である。．また 2 例が検查後死亡してい る. 急性心不全が 1 例で食道㨁達㭘査後 7 日して死亡し た6ので73才女子食道第三狭窟モ千異物である。他の 1 例は 2 才女子の 5 円硬貨食道第二狭窄異物で検査後羿 日気胸で死亡している。死亡にはいたらなかつたが，3 才男子，10月硬貨食道第 3 狭㗱異物で食道直達鏡検査を 行い異物摘出し得ず胃内へ落下術後肺気腄上り気胸を拉 こし，更に乎吸困難で気管切開を施行，血胸で入院加療 した例が1例ある。主た乳幼览で約一ケ月来原因不明の 発熱が時々あり，固形物摂食時澏吐し，小览积で自家中 毒でないかといわ的食道第一狭窄に硬貨異物を発見した 例がある，気管倨頭異物では殆ど乳奻児であるが当科を 受診するまでに内科小思稍で数ヶ月にわたり気管支资, 気管支喘息、肺炎，無気肺と診断さ机当稿受診してはじ めて異物を確認されたものが11例るあり，魚骨片，豆 類，才カキ，卵設等が認められた。詳細は別火報告す

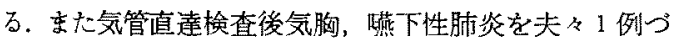
つ㒛めている. 死亡例は 3 例でいずれる 5 才以下の乳幼 罗で泋きいるの皮，大豆による䇪息例およびシッカロー ル気道誤引による肺炎死例であつた。

\section{6. 貨幣異物}

食道異物症 507 例中 294 例 $58 \%$ ，胃腸異物 170 例中 78 例 $46 \%$ と症過半数を占的る貨幣異物について梌討 を加えた，10 円硬貨が、倒的に多く次いで5 円貨とな つている，恋た重複異物が7例にみられ10円貨と1円 貨枚重複をのぞいていずれも10円2枚重複異物であつ た.この貨幣異物の $85 \%$ が 5 才までの乳幼児である隶 に注意したい (第 4,9,11 表).

\section{7. 異物症の変逛}

昭和 7 年より昭和 40 年までの 34 年間に阪大耳鼻咽搌 科教室に括ける異物症の变要を阪大の過去の統計（山

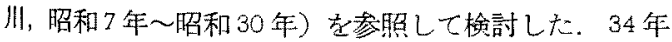
間の外来新患々者数は約 36 万人で体内に異物を認めた 異物䇥患者数怔 3,984 例で約 $1 \%$ 强に相当する，第 2 図 の如〈異物定絵数では炤和 10 年より18 年頃までに年間 130 万至 140 例文られた子のが，太平洋戦争末期より終 楼2,3年間になると激減し，25，26 年頃より一時增加し はじめ最近昭和38年頃よりまた激增の傾向にある。食道 異物もこれと同様の傾向をとつている，気管喉頭異物は
第 9 表 貨敒異物の年度別推移

\begin{tabular}{|c|c|c|c|c|c|c|c|c|}
\hline 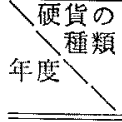 & $\begin{array}{l}\overrightarrow{\text { 华 }} \\
\text { 貨 }\end{array}$ & $\begin{array}{l}\text { 五 } \\
\text { 円 } \\
\text { 货 }\end{array}$ & $\begin{array}{l}+ \\
\text { 界 } \\
\text { 䝨 }\end{array}$ & $\begin{array}{l}\frac{\text { 五 }}{1} \\
\text { 用 } \\
\text { 貨 }\end{array}$ & 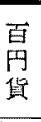 & 計 & $\begin{array}{l}\text { 食件 } \\
\text { 道数 }\end{array}$ & $\begin{array}{l}\text { 俏件 } \\
\text { 晹数 }\end{array}$ \\
\hline 昭和 31 年 & 1 & 16 & 21 & & \multirow{10}{*}{2} & 38 & 26 & $11^{*}$ \\
\hline 32 & 2 & 7 & 27 & 1 & & 37 & $30^{*}$ & 6 \\
\hline 33 & 1 & 3 & 19 & & & 23 & 17 & 6 \\
\hline 34 & & 5 & 20 & & & 25 & 19 & 6 \\
\hline 35 & & 11 & 20 & 1 & & 32 & 26 & 6 \\
\hline 36 & & 2 & 17 & & & 19 & 19 & 0 \\
\hline 37 & 1 & 10 & 19 & 1 & & 31 & $26^{*}$ & 4 \\
\hline 38 & 2 & 19 & 33 & & & 56 & 44 & $11^{*}$ \\
\hline 39 & 2 & 15 & 41 & 1 & & 59 & 46 & 13 \\
\hline \multirow[t]{2}{*}{40} & 2 & 5 & 50 & 1 & & 59 & $*_{41} * *$ & 15 \\
\hline & 11 & 93 & 267 & 5 & 2 & 379 & 294 & 78 \\
\hline
\end{tabular}

※は硬貨 2 枚重複異物例を示す

第 10 表食道異物应と食道周因膿瘍

\begin{tabular}{|c|c|c|c|c|}
\hline & $\begin{array}{l}\text { 黑物 症 } \\
\text { 兹数 }\end{array}$ & 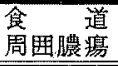 & 死 & ᄂ \\
\hline 昭和 $7 \sim 16$ 年(10年間) & 841 & 19 & & 7 \\
\hline 昭和17 23年 $(7$ 年間) & 557 & 30 & & 5 \\
\hline 昭和24〜30年( 7 年間) & 437 & 10 & & 1 \\
\hline 昭和 $31 \sim 40$ 年(10年間) & 507 & 6 & & 0 \\
\hline
\end{tabular}

表 11 表 货幣異物变邆

\begin{tabular}{|c|c|c|c|c|c|c|c|c|}
\hline & $\begin{array}{l}\vec{T}+ \\
\sim \\
\text { ミ 銭 }\end{array}$ & $\begin{array}{l}\text { 五 } \\
十 \\
\text { 銭 }\end{array}$ & $\begin{array}{l}- \\
\text { 円 }\end{array}$ & $\begin{array}{l}\text { 五 } \\
\text { 円 }\end{array}$ & $\begin{array}{l}+ \\
円\end{array}$ & $\begin{array}{l}\underset{7}{\dagger} \\
\text { 円 }\end{array}$ & $\begin{array}{l}\text { 百 } \\
\text { 円 }\end{array}$ & 計 \\
\hline 昭25 & 2 & I & 1 & $\vartheta$ & & & & 13 \\
\hline 26 & & 3 & 3 & 9 & & & & 15 \\
\hline 27 & & 3 & 5 & 26 & & & & 34 \\
\hline 28 & & & & 15 & 7 & & & 22 \\
\hline 29 & & & & 5 & 25 & & & 30 \\
\hline 30 & & & & 8 & 16 & & & 24 \\
\hline 31 & & & 1 & 16 & 21 & & & 38 \\
\hline 32 & & & 2 & 7 & 27 & l & & 37 \\
\hline 33 & & & 1 & 3 & 19 & & & 23 \\
\hline 34 & & & & 5 & 20 & & & 25 \\
\hline 35 & & & & 11 & 20 & 1 & & 32 \\
\hline 36 & & & & 2 & 17 & & & 19 \\
\hline 37 & & & 1 & 10 & 19 & 1 & & 31 \\
\hline 38 & & & 2 & 19 & 33 & & 2 & 56 \\
\hline 39 & & & 2 & 15 & 41 & I & & 59 \\
\hline 40 & & & 2 & 5 & 50 & 1 & & 59 \\
\hline
\end{tabular}


第 2 図翼物症の変邆

昭和 7 年 40年

外来新患々者数

玫物症患者数

約 36 万名

3,984 名

- - 程物拉總数

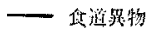

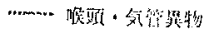

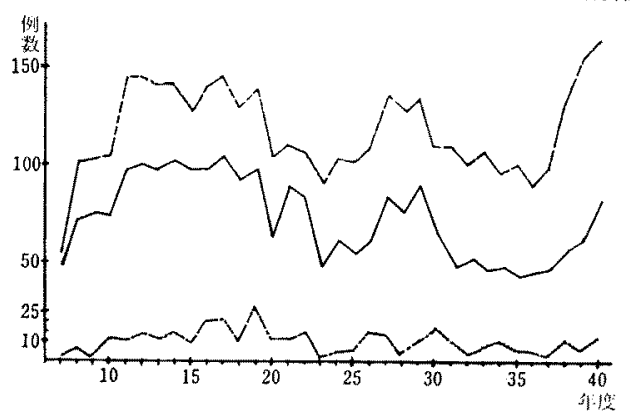

第3图食道買物の变邆

昭和7年 40年

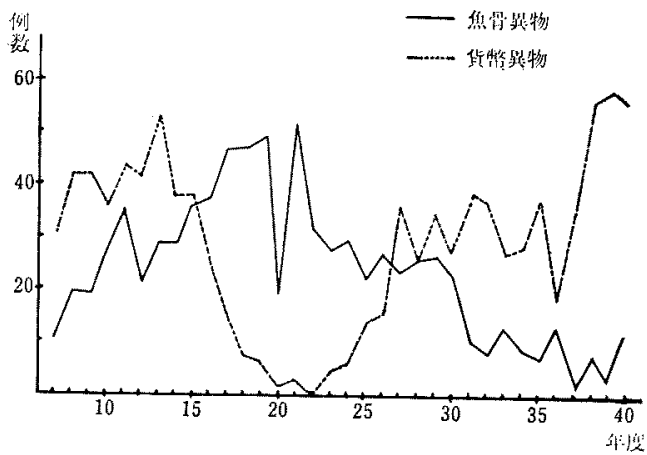

各年ほぼ一定で10例前後で左程の增減はない，食道異物 では貨漦異物，魚骨罢物が相反する変化を示している。 すなわ第 3 図の如く貨撆罢物は戦前多くあつたもの が，戦争末期に少く，20，21，22 年預は皆無上なり最近 また增加している．魚冎買物は戦前多く最近減少の傾向 を示している，また食道周囲膿瘍についてみると第 10

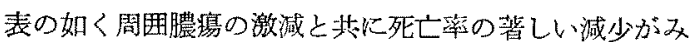
られる，また第11表では 5 円便貨及び10 円硬貨が压倒 的に多いが，その年代の流通貨幣も文ら饥る。

\section{8.小括}

炤和 36 年以第 2 室戸台風で9,10月休猃のため新急外 来数は少いが，昭和 31 年から 40 年まで年間約 I万1 千 名の外来新患々渚があり，異物症はその約 $1 \%$ にみられ る、第1表から分るご上?罢物唗のらたがいで当科を受
診しているものがここ2,3年来多くなり異物未確茨症例 がその30\%にも達している。これは救急制度の普及や その他倳々な社会事情に上るものと思われる。

第 1 図上り異物症の過半数は乳幼児にみられる。乳幼 罗では食道異物は貨幣が主で，気管脘頭暴物はとの生命

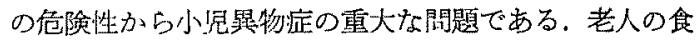

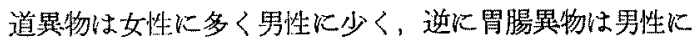
〈女性に少い事実は男女間の食事喏好，食事時緒情その 他の問題等がからんでいて與味深いものである. また老 人に獣肉片類をはじめ食塊食道瑟物の多い原因はまず自 然雨と義蒾との感賞の差異が閔係し，また柬がないから よく啫まないことにある、義歯と永久潾とでは食物の阻

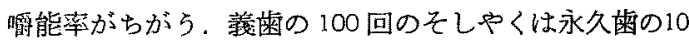
回位のそれに相当するといわれている。また，老人にな

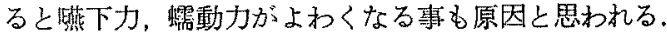

食道異物惊第 6 表の如くその70\% が第一狭窄部に介 在している。これには食道の解部学的事実より説时がつ けられよ5。最近若い年代に義圈暴物が多くなつてきた が美容短正の面より義菌を用いる事が多くなつたためで ある5．乳奻睍で慢性気管支炎，喘息，肺炎等と診断さ れ加療続けていたが治らず，䒨頭気管異物であつた例も 多く，また原因不眀の発熱で食道硬貨異物であつた遥延 異物等乳幼胃之異物症との関俰はふか心，異物症の症状 としては食道では藏下痛，咽頭痛（異物がな和介在すれ

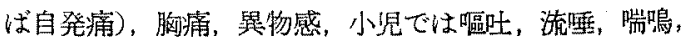
下咽頭では呼吸困難等であり，喉頭気管では唂濑，喘 鳴，乎吸困難等が主である。また営苝の動機は遊戲中， 食事中，仕事中等 case by case であるが，乳奻少で手

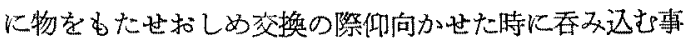
が多く，針，鈿等を口にらくんで仕事をしている人は一 寸した要因で翼物症となつている，最近は少くなつた

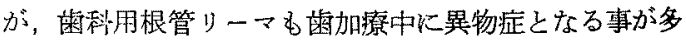

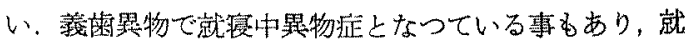

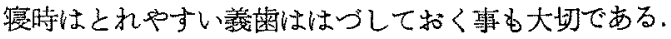

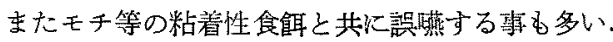

全併拉としては第 8,14 表の如くであるが，耷異物で

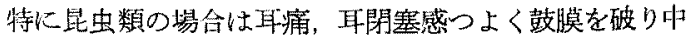
耳炎を併登しているものがかなりある。食道周围膿瘍は 第 8,10表の如く年々減少し死亡も戦能に比へ $1 / 3$ より $1 / 5$ K，最近では殆どなく，抗生刘の恩恵は大である。 老人小胃で食道第 2 狭害部異物はしばしば気管，左気管 支を王迫する赫多く，しばしば呼吸困難で食道鏡を拔去 しなければならず允分な注意が必琶である。炤租7年よ 


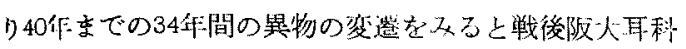
には異物症はやや少くなつてきているようである。貨幣 異物では戦前多からたものが，金属回収のたけなわであ つた戦争の影響のため昭和 $20 \sim 22$ 年は殆どなく最近イ ンフレの傾向のためかまた多くなつてきている，また魚 骨異物がたんだん少くなり肉食が多くなつた事や，食事 料理法の問題等が関係していると思われる。

$$
\text { B) 各 論 }
$$

我今は異物症患者飞受部時異物滞留部位により部位を わけた。 以下各項目についてのべる。

1. 耳異 物

耳異物は 10 年間に 87 例で年間 8〜10 例である. 全罢 物定の $8 \%$ に相当している，昆虫類が比較的多く約 $37 \%$ を占めている，玩具類及びその部分品（オモチヤのピス

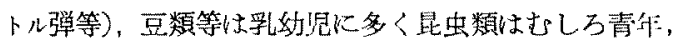
中年に多いまな乳奻思ではネックレス珠，果実種子， ケシゴム破片等が多く青，中年代では綿花，マッ千軸， 毛，木の葉，紙，耳かき尖端部等が多か心第 2， 12，13表)．また第 14 表の如く7例に中耳炎住発をみて いる.

2. 鼻 異 物

第 2,15表にみる如く 41 例の奥異物例をみるが，こ机 は全異物症の $4 \%$ に相当する．奥異物は殆どが 5 才以下 の乳幼巟でオモチヤのピストル弾丸等玩具類及びその破 片，豆類の洼か，パチンコ玉，果実の種子，ボタン，ネ ックレス，ビーズ珠等球状のるのが多い，青年期の舆異 物では鼻手術後と思われるガーゼ片が 3 例あつた。

第 12 表 年度別耳異物の䁈類

\begin{tabular}{|c|c|c|c|c|c|c|c|c|}
\hline 年 惯 & 男 & 女 & $\begin{array}{l}\text { 昆 } \\
\text { 虫 } \\
\text { 類 }\end{array}$ & $\begin{array}{l}\text { 耳 } \\
\text { 力 } \\
\neq\end{array}$ & $\begin{array}{l}7 \\
乇 \\
f \\
+\end{array}$ & $\begin{array}{l}\text { 具 } \\
\text { 類 }\end{array}$ & $\begin{array}{l}Z_{C} \\
\Phi \\
\text { 优 }\end{array}$ & 言 \\
\hline 炤租31笔 & 5 & 6 & 3 & 1 & 1 & 0 & 6 & 11 \\
\hline 32 & 3 & 2 & 2 & 1 & 0 & 0 & 2 & 5 \\
\hline 33 & 4 & 6 & 2 & 0 & 3 & 1 & 4 & 10 \\
\hline 34 & 7 & 3 & 2 & 0 & 1 & 1 & 6 & 10 \\
\hline 35 & 4 & 1 & 2 & 0 & 0 & 0 & 3 & 5 \\
\hline 36 & 4 & I & 2 & 0 & 0 & 1 & 2 & 5 \\
\hline 37 & 9 & 1 & 6 & 0 & 1 & 0 & 3 & 10 \\
\hline 38 & 3 & 4 & 3 & 1 & 1 & 2 & 0 & 7 \\
\hline 39 & 7 & 4 & 4 & 3 & 1 & 2 & 1 & 11 \\
\hline 40 & 8 & 5 & 5 & 1 & 4 & 0 & 3 & 13 \\
\hline 票. & 54 & 33 & $\Xi 1$ & 7 & 12 & 7 & 30 & 87 \\
\hline
\end{tabular}

第 13 表 作年令別奋買物の栖頪

\begin{tabular}{|c|c|c|c|c|c|c|c|c|}
\hline 年 令 & 男 & 女 & $\begin{array}{l}\text { 昆 } \\
\text { 虫 }\end{array}$ & $\begin{array}{l}\text { 耳 } \\
\text { 力 } \\
\text { f }\end{array}$ & \begin{tabular}{l} 
J \\
\multirow{z}{*}{} \\
+ \\
+
\end{tabular} & $\begin{array}{l}\text { 豆 } \\
\text { 類 }\end{array}$ & $\begin{array}{l}\text { 艺 } \\
\text { 员 } \\
\text { 他 }\end{array}$ & 計 \\
\hline 0〜 5才 & 9 & 8 & 1 & 3 & 6 & 2 & 5 & 17 \\
\hline $6 \sim 9$ & 12 & 5 & 1 & 0 & 5 & 3 & 8 & 17 \\
\hline $10 \sim 15$ & 3 & 1 & 1 & 0 & 0 & 1 & 2 & 4 \\
\hline $16 \sim 19$ & 7 & 2 & 5 & 0 & 1 & 0 & 3 & 9 \\
\hline $20 \sim 29$ & 14 & 8 & 8 & 3 & 0 & 1 & 10 & 22 \\
\hline $30 \sim 39$ & 6 & 2 & 7 & 0 & 0 & 0 & 1 & 8 \\
\hline $40 \sim 49$ & 3 & 3 & 5 & 1 & 0 & 0 & 0 & 6 \\
\hline $50 \sim 59$ & 0 & 4 & 3 & 0 & 0 & 0 & 1 & 4 \\
\hline 60 以上 & 0 & 0 & 0 & 0 & 0 & 0 & 0 & 0 \\
\hline 计 & 54 & 33 & 31 & 7 & 12 & 7 & 30 & 87 \\
\hline
\end{tabular}

第 14 表 正異物と合敉症

\begin{tabular}{|c|c|c|c|c|c|c|c|}
\hline 店例 & 性年 & $\begin{array}{l}\text { 買物の } \\
\text { 類 }\end{array}$ & 毁 機 & 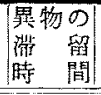 & 主 & 訴 & 合併堑 \\
\hline I. & 82 & 刀㵩 & $\begin{array}{l}\text { 兄が遊き } \\
\text { 中い扎た }\end{array}$ & 不 & 年: & 痛 & 中耳 \\
\hline K. & $\hat{\delta}$ & $\begin{array}{c}\text { こが权 } \\
\text { 虫 }\end{array}$ & |迷 & 2過間 & & 痛 & 中耳 \\
\hline N. & 936 & 木 片 & $\mid \begin{array}{l}\text { フキンか } \\
\text { けかっつ } \\
\text { ささる }\end{array}$ & $\begin{array}{ll}7 & \text { 日 }\end{array}$ & & $\begin{array}{l}\text { 㯰 } \\
\text { 鳴 }\end{array}$ & 中 I \\
\hline N. & 841 & 蛾 & 迷 & 不 明 & & 痛 & 中耳 \\
\hline $\mathrm{H}$. & $\begin{array}{llll}8 & 10\end{array}$ & ア父キ & 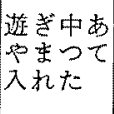 & レケ月 & $\begin{array}{l}\text { 耳 } \\
\text { 出血 } \\
\text { 蜼 }\end{array}$ & $\begin{array}{l}\text { 痡 } \\
\text { 性 } \\
\text { 漏 } \\
\text { 㯖 }\end{array}$ & 中 \\
\hline$Y$. & 818 & 蚂 & 迷 & 20 日 & $\begin{array}{l}\text { 耳 } \\
\text { 塞 }\end{array}$ & 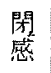 & $\begin{array}{l}\text { 中耳 炎 } \\
\text { 耳管狄 }\end{array}$ \\
\hline $\mathbb{N}$ & 917 & $\begin{array}{c}こ か ゙ れ 2 \\
\text { 虫 }\end{array}$ & 迷 & 1時間 & $\begin{array}{l}耳 \\
\text { め } \\
\text { 失 }\end{array}$ & $\begin{array}{l}\text { 痛 } \\
\vdots \\
\text { 神 }\end{array}$ & 堌膜裂自 \\
\hline
\end{tabular}

第 15 表 年命別奥異物の種類

\begin{tabular}{|c|c|c|c|c|c|c|c|c|c|}
\hline 年 令 & 男 & 女 & 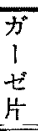 & $\begin{array}{l}\text { 緥! } \\
\text { 花 }\end{array}$ & $\begin{array}{l}才 \\
\epsilon \\
\sigma \\
+\end{array}$ & $\begin{array}{l}\text { 紙 } \\
\text { 片 }\end{array}$ & $\begin{array}{l}\text { 豆 } \\
\text { 類 }\end{array}$ & $\begin{array}{l}\text { z } \\
\text { の } \\
\text { 他 }\end{array}$ & 計 \\
\hline $0 \sim 5 x$ & 20 & 14 & 0 & 3 & 11 & 3 & 5 & 12 & 34 \\
\hline $6 \sim 9$ & 2 & 1 & 0 & 0 & 0 & 1 & 0 & 2 & 3 \\
\hline $10 \sim 15$ & 0 & 0 & 0 & 0 & 0 & 0 & 0 & 0 & 0 \\
\hline $16 \sim 19$ & 0 & 0 & 0 & 0 & 0 & 0 & 0 & 0 & 0 \\
\hline $20 \sim 29$ & 3 & 1 & 3 & 0 & 0 & 0 & 0 & 1 & 4 \\
\hline 30 以上 & 0 & 0 & 0 & 0 & 0 & 0 & 0 & 0 & 0 \\
\hline at & 25 & 16 & 3 & 3 & 11 & 4 & 5 & 15 & 41 \\
\hline
\end{tabular}


第 16 表 上嘼・上呕嘼累物

\begin{tabular}{|c|c|c|c|c|c|c|c|c|}
\hline 症 例 & & $\begin{array}{l}\text { 年 } \\
\text { 令 }\end{array}$ & 異物の種類 & 霃留部位 & 機 & 滞留時間 & 主 & 摘 出方 法 \\
\hline S. K & 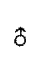 & 21 & & 右上顎洞 & $\lambda$ & 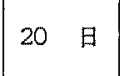 & 視 & 右上䝷洞根本手 \\
\hline Y. T. & $\delta$ & 48 & 銃 弹 破 片 & 左上靧洞 & 戦争中左服下部より入る & 24 年 & 左膿様舆漏 & レ線にて碓認 \\
\hline K. Y. & $\delta$ & 66 & 焼夷弹の信管研 & 上咽頭 & 不発 の信管爆発 & 15 年 & $\begin{array}{l}\text { 顔面重生感 } \\
\text { 頚 痛 }\end{array}$ & Kて \\
\hline M. 1 & $\hat{\delta}$ & 14 & 釗 & 頭 & 曼 & 间 & 咽 頭 痡 & $\begin{array}{l}\text { 後率鏡下鉗子で } \\
\text { 除去 }\end{array}$ \\
\hline
\end{tabular}

\section{3. 上顠及び上咽頭異物}

上頡異物 2 例，上哂頭異物 2 例計 4 例でいずれも金属 類である。こ机は全異物症の0.4\%にあたる、症例を第 16 表沶示。

\section{4. 中咽頭及び下咽頭異物}

中咽頭異物症 138 例，下咽頭翼物症 37 例で夫々全異 物症の $13 \% ， 3 \%$ にあたりその内訳怯第6表の如くであ

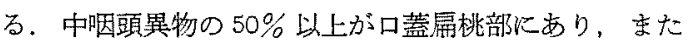
中咽頭異物 138 例中 124 例が魚骨異物で $90 \%$ 占めそ

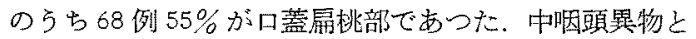
して魚骨以外に怯針，釷，ピン類，ガラス片，竹串等で あつた：また下咽頭異物も同様な傾向で大多数が魚骨で 梨子状简に王倒的に多かつた。

\section{5. 䐅頭・気管翼物}

気管・知頭異物は6 63 例で 全異物症の $6 \%$ K相当し第 6,8,17,18 表の如く異物の種類ししてはマチ針，ピン， 根管りーマが多く，论いでピーナッ，ソラ豆等の豆類が

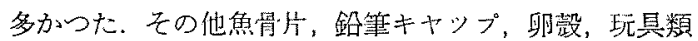

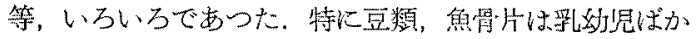
りで，豆類は致死的因子を多く含んでいるたけけ小罗買 物症の大切な問題である。屯た声門裂，声門下腔に介在 した魚骨片は嗄声以外に特別な臨床症状なく，いろいる な小児呼吸疾患と見諨れる恐れもある。下気道異物で死 亡したのは1才6ケ月男子，垁芋の皮気管異物，1才男 子大豆気管分岐部異物であつた，また 8 ケ月男子でシッ カロールを頭からかぶり，鼻腔口腔上り䏫内まで吸引 し，呼吸面の減少と肺炎で翌日死亡したすのもあり，て の他死亡にはいたらないが，シッカロール吸引例が 2 例あり，いずれも乳幼胃た゚け問題となる。 また大人で は，針，ピン，釘，ネジ，根管リーマ（分類上針，ピン 類に含导）等尖鋭金属異物が殆えどで，仕事中，治療 中，或は口に含んでいておどかされたり，笑ったり，欠

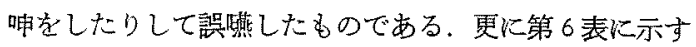

第 17 表 年度別㬋頭気管異物の種類

\begin{tabular}{|c|c|c|c|c|c|c|}
\hline 年度】種類 & $\begin{array}{l}\text { 針 } \\
ヒ^{\circ} \\
ン\end{array}$ & $\begin{array}{l}\text { 鎬 } \\
\star \\
\forall \\
\forall\end{array}$ & $\begin{array}{l}\text { 可 } \\
\text { 類 }\end{array}$ & $\begin{array}{l}\text { 魚 } \\
\text { 骨 } \\
\text { 片 }\end{array}$ & $\begin{array}{l}\text { そ } \\
\text { の } \\
\text { 他 }\end{array}$ & 辟 \\
\hline 昭和31年 & 4 & 0 & 1 & 0 & 4 & 9 \\
\hline 32 & 1 & 0 & 0 & 0 & 4 & 5 \\
\hline 33 & 3 & 0 & 2 & 0 & 3 & 8 \\
\hline 34 & I & 1 & 0 & 0 & 4 & 6 \\
\hline 35 & 0 & 1 & 0 & 1 & 2 & 4 \\
\hline 36 & 0 & 0 & 1 & 2 & 2 & 5 \\
\hline 37 & 0 & 1 & 0 & 0 & 3 & 4 \\
\hline 38 & 3 & 1 & 2 & 1 & 2 & 9 \\
\hline 39 & 3 & 0 & 2 & 0 & 0 & 5 \\
\hline 40 & 2 & 0 & 5 & 0 & 1 & 8 \\
\hline 郭 & 17 & 4 & 13 & 4 & 25 & 63 \\
\hline
\end{tabular}

第 18 表 年令別喉頭気管巽物の種類

\begin{tabular}{|c|c|c|c|c|c|c|c|c|}
\hline 年 令 & 是 & 女 & $\begin{array}{l}\text { 針 } \\
ヒ^{\circ} \\
ン\end{array}$ & $\begin{array}{l}\text { 釗 } \\
\star \\
シ \\
\forall\end{array}$ & $\begin{array}{l}\text { 豆 } \\
\text { 類 }\end{array}$ & $\begin{array}{l}\text { 魚 } \\
\text { 骨 } \\
\text { 占 }\end{array}$ & $\begin{array}{l}\text { そ } \\
\text { 足 } \\
\text { 他 }\end{array}$ & 計 \\
\hline $0 \sim 5 x$ & 19 & 18 & 7 & 1 & 12 & 4 & 13 & 37 \\
\hline $6 \sim 9$ & 4 & 5 & 4 & 0 & 0 & 0 & 5 & 9 \\
\hline $10 \sim 15$ & 3 & 0 & 0 & 1 & 0 & 0 & 2 & 3 \\
\hline $16 \sim 19$ & 0 & 0 & 0 & 0 & 0 & 0 & 0 & 0 \\
\hline $20 \sim 29$ & 2 & 5 & 4 & 0 & 0 & 0 & 3 & 7 \\
\hline $30 \sim 39$ & 1 & 2 & 1 & I & 0 & 0 & 1 & 3 \\
\hline $40 \sim 49$ & 0 & 2 & 0 & 0 & 1 & 0 & 1 & 2 \\
\hline $50 \sim 59$ & 2 & 0 & 1 & 1 & 0 & 0 & 0 & 2 \\
\hline 60 以上 & 0 & 0 & 0 & 0 & 0 & 0 & 0 & 0 \\
\hline 幛 & 31 & 32 & 17 & 4 & 13 & 4 & 25 & 63 \\
\hline
\end{tabular}


如く気管異物 48 例中，主気管が一番多く，左右気管支

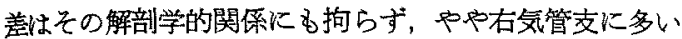
程度に過ぎなからた。特に，大人では右第管支に多い が，乳奻奣では必ずしも右気管支に多いとはい之ないよ うであつた。

\section{6. 食道異物}

我教室の異物应 1043 例中丁度 50\% が食道基物で異物 症といえば食道異物をさす位である。したがのて年間約

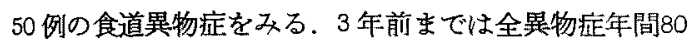
例中約 40 例であつた のが，その後年間 全異物症 150 例中的70 例がそれで阪大ではここ数年間異物店の半数 以上が食道である(第 $2 ， 20$ 表). 食道異物の半数以上

第 19 表 年令・性別食道異物の種類

\begin{tabular}{|c|c|c|c|c|c|c|c|c|c|c|c|}
\hline 年 & 男 & 女 & 憋 & $\begin{array}{l}\text { 魚 } \\
\text { 骨 } \\
\text { 片 }\end{array}$ & 歯 & 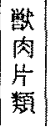 & $\begin{array}{c}\text { 舎 } \\
ヒ^{\circ} \\
\text { Y }\end{array}$ & 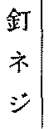 & $\begin{array}{l}j \\
b \\
b \\
b \\
p\end{array}$ & $\begin{array}{l}z \\
\infty \\
\text { 地 }\end{array}$ & 棓 \\
\hline $0 \sim 5 t$ & 76 & 132 & 258 & 1 & o & 2 & 9 & $0_{1}$ & 15 & 23 & \\
\hline & 2 & 13 & 28 & 0 & 0 & o & $\mathrm{o}$ & o & 2 & 3 & \\
\hline & 4 & & 2 & o & 0 & o & 1 & o & $I_{1}$ & 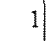 & \\
\hline & 7 & 7 & 4 & 2 & 1 & 1 & 2 & 0 & 0 & 4 & \\
\hline 29 & 15 & 13 & 2 & 11 & 4 & 4 & 1 & 0 & 0 & 6 & \\
\hline 39 & 11 & 13 & 0 & 12 & 9 & 1 & 1 & 0 & 0 & 1 & \\
\hline & 17 & 2 & 0 & 8 & 11 & 4 & 1 & 0 & 0 & 1 & \\
\hline $50 \sim 59$ & 10 & 24 & 0 & 11 & 7 & 10 & 1 & 0 & 0 & 5 & \\
\hline 以上 & 13 & 23 & 0 & 12 & 7 & 13 & 0 & 1 & 0 & 3 & \\
\hline & 73 & 233 & 294 & 51 & 39 & 35 & 10 & 1 & & 47 & \\
\hline
\end{tabular}

第 20 表 年度別食道異物の種類

\begin{tabular}{|c|c|c|c|c|c|c|c|}
\hline 年 度 & $\begin{array}{l}\text { 炛 } \\
\text { 幣 }\end{array}$ & $\begin{array}{l}\text { 魚 } \\
\text { 骨 } \\
n^{\prime}\end{array}$ & $\begin{array}{l}\text { 義 } \\
\text { 崡 }\end{array}$ & $\begin{array}{l}\text { 鼠 } \\
\text { 肉 } \\
\text { 片 }\end{array}$ & 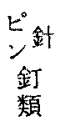 & $\begin{array}{l}r \\
の \\
\text { 他 }\end{array}$ & 計 \\
\hline 昭和 31 年 & 26 & 6 & 2 & 5 & 1 & 6 & 46 \\
\hline 32 & 30 & 5 & 2 & 3 & 2 & 6 & 48 \\
\hline 33 & 17 & 9 & 3 & 1 & 2 & 10 & 42 \\
\hline 34 & 19 & 5 & 5 & 4 & 2 & 8 & 43 \\
\hline 35 & 26 & 4 & 2 & 0 & 0 & 4 & 36 \\
\hline 36 & 19 & 10 & 0 & 3 & 1 & 5 & 38 \\
\hline 37 & 26 & 1 & 4 & 2 & 1 & 4 & 38 \\
\hline 38 & 44 & 5 & 6 & 4 & 3 & 6 & 68 \\
\hline 39 & 46 & 2 & 9 & 6 & 1 & 8 & 72 \\
\hline 40 & 41 & 9 & 6 & 7 & 3 & 10 & 67 \\
\hline 棓 & 294 & 56 & 39 & 35 & 16 & 67 & 507 \\
\hline
\end{tabular}

（58\%）が貨幣異物で次いで魚骨片，義棶，獣肉片類等 が多い，第6 表より食道異物 607 例中 365 例 $72 \%$ が第

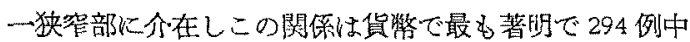
250 例 $85 \%$ が第一狭窄部であつた，魚骨片，義娄，獣 肉片類俚第一，二狭窄同じ程度にみられた，針ピン類で 食道に介在するのはやはり第一狭窄部化多いようであ

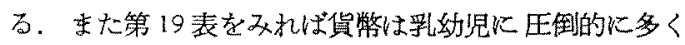
魚骨片は中年に，義茵，獣肉片は老年に多いが最近義橉 は前述の如く若い年代にる多くなつている，なた乳幼児 では玩具抏よびその部分品が多く基石，乳首の金具，ボ タン類，押ピン，画鋲類等も多く敵出に困難をきたし， しばしば胃内へ落下するすのである。

第 21 表 年度別胃腸異物の種類

\begin{tabular}{|c|c|c|c|c|c|c|c|c|c|}
\hline 年 度 & 男 & 女 & $\begin{array}{l}\text { 針 } \\
\text { ピ } \\
\text { ン }\end{array}$ & 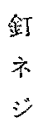 & 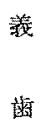 & 货 & $\begin{array}{l}\text { to } \\
\text { b } \\
b \\
p \\
p\end{array}$ & $\begin{array}{l}\text { 先 } \\
\text { 他 }\end{array}$ & 計 \\
\hline 昭和 31 年 & 13 & 5 & 3 & 1 & 1 & 11 & 2 & 0 & 18 \\
\hline 32 & 9 & 2 & 2 & 2 & 0 & 6 & 1 & 0 & 11 \\
\hline 33 & 11 & 3 & 4 & 3 & 0 & 6 & 0 & 1 & 14 \\
\hline 34 & 11 & 3 & 3 & I & I & 6 & 2 & 1 & 14 \\
\hline 35 & 15 & 4 & 5 & 3 & 2 & 6 & 2 & 1 & 19 \\
\hline 36 & 4 & 0 & 3 & 0 & 0 & 0 & 1 & 0 & ${ }^{4}$ \\
\hline 37 & 8 & 1 & 2 & 1 & 0 & 4 & 2 & 0 & 9 \\
\hline 38 & 14 & 7 & 5 & 3 & 1 & 11 & 1 & 0 & 21 \\
\hline 39 & 18 & 15 & 12 & 2 & 1 & 13 & 3 & 2 & 33 \\
\hline 40 & 21 & 6 & 5 & 3 & 1 & 15 & 2 & 1 & 27 \\
\hline 訫 & 124 & 46 & 44 & 19 & 7 & 78 & 16 & 6 & 170 \\
\hline
\end{tabular}

第 22 表 年令別胃晹異物の種類

\begin{tabular}{|c|c|c|c|c|c|c|c|c|c|}
\hline 年 令 & 男 & 女 & $\begin{array}{c}\text { 針 } \\
ヒ^{\circ} \\
y\end{array}$ & $\begin{array}{l}\text { 鉬 } \\
\text { 市 } \\
*\end{array}$ & $\begin{array}{l}\text { 義 } \\
\text { 䅦 }\end{array}$ & $\begin{array}{l}\text { 鼬 } \\
\text { 䏿 }\end{array}$ & $\begin{array}{l}\text { 损 } \\
b \\
b \\
p\end{array}$ & $\begin{array}{l}\text { そ } \\
9 \\
\text { 地 }\end{array}$ & 棓 \\
\hline $0 \sim 5 才$ & 67 & 31 & 17 & 2 & 0 & 61 & 13 & 5 & 98 \\
\hline $6 \sim 9$ & 20 & 5 & 4 & 2 & 0 & 16 & 3 & 0 & 25 \\
\hline $10 \sim 15$ & 3 & 2 & 4 & I & 0 & 0 & 0 & 0 & 5 \\
\hline $16 \sim 19$ & 12 & 1 & 8 & 3 & 1 & 1 & 0 & 0 & 13 \\
\hline $20 \sim 29$ & 6 & 5 & 6 & 1 & 3 & 0 & 0 & 1 & 11 \\
\hline $30 \sim 39$ & 7 & 1 & 4 & 2 & 2 & 0 & 0 & 0 & 8 \\
\hline $40 \sim 49$ & 1 & 1 & 0 & 1 & 1 & 0 & 0 & 0 & 2 \\
\hline $50 \sim 59$ & 4 & 0 & o & 4 & 0 & 0 & 0 & 0 & 4 \\
\hline 60 以上 & 4 & 0 & 1 & 3 & 0 & 0 & 0 & 0 & 4 \\
\hline 毃 & 124 & 46 & 44 & 19 & 7 & 78 & 16 & 6 & 170 \\
\hline
\end{tabular}


7. 塌儤基物

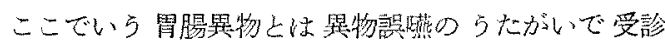
し，上線透視及び撮影ですでに胃腸部に罢物を磪認し得 たもので，彷つて異物の種類ししてレ線造影可能なる

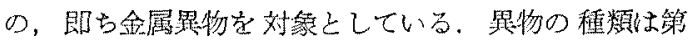
21，22表の如くである．男：女＝124：46で男性は女性 の約3倍である点，食生活との関連に抌いて與誅があ

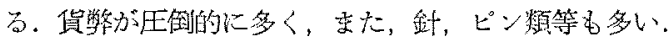

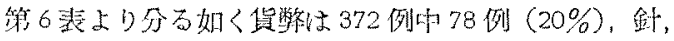

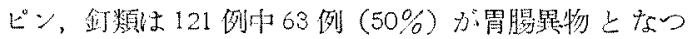

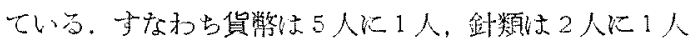
が初診㭙既火胃腸内心落下している整を元し，これ等の 界物些の際にはあるてずに胃腸部のレ線透視撮影を必ず

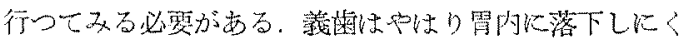
く，楁下は10\%程度である。

\section{8. 小插}

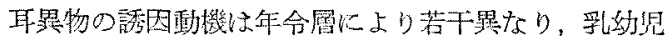
で鼻異物同様，同じ年頃同志遊えでいて，ネックレー

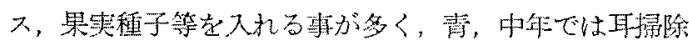

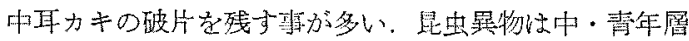
に多く特に夏夜拈てくまで起きている人化多い，耳異物

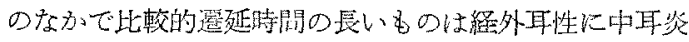

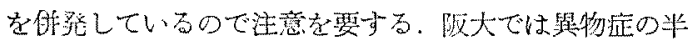

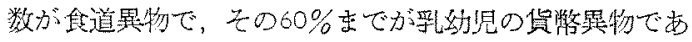

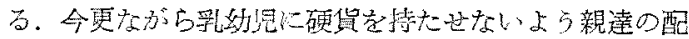

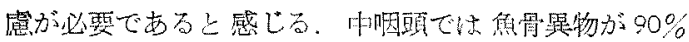
もあること恃日本人の食生活の一端を示しているである

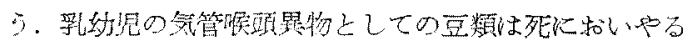

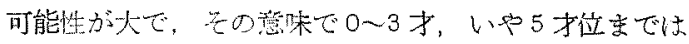
豆類を与えない漞䛭の心遣いがあつてほしい，乳奻兑ン ソカロールもこれを四吸道に吸引した場合，支の好置が 因蜼なため，艺の取报いに注意しなければならない小 胃呼吸器疾患之间䔔光た声門烈，声門下腔 異物例もあ

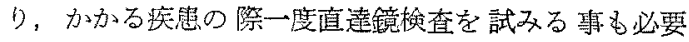
で，小韭科医にその配慮を要望したい，最後に異物症の らたがいで受㟝した場合，たとへ他院でレ線撮影がして あつても，当科受骖まてに留内に落下している事もあ

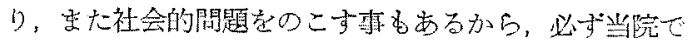

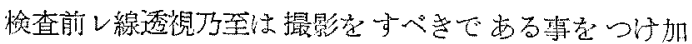

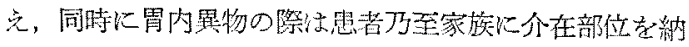

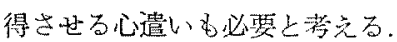

\section{C) 結語}

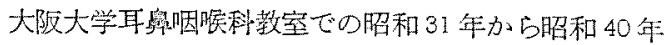
まで10年間に括ける罢物应を統計的に雉察し次の上ら な結果をえた。

1. 翼物症例数心1，043例で外来術患々者の䄪 $1 \%$ 安 少している。
2. $\%$ ，胃晹 170 例 $(16 \%)$ ，気管㭽頭 63 例 $(6 \%)$ ，耳 87 例 $(8 \%)$ ，齄 41 例 (4\%)，上顠 2 例 $(0.2 \%)$ の異物症例 となつている.

3. 異物症の過半数が孚纤児にみられ，䭒道貨幣異物 が殆んどで氛管罢物の豆類と共に小思異物症の問題点と なつている。

4. 食道鼠物 507 例中その $72 \%$ が第一狭窄部に介在

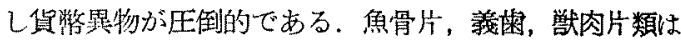

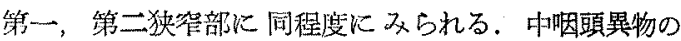
$90 \%$ が魚骨片でその 50\%以上が口蓋扁桃部にある。気 管暴物は 48 例で気管分岐部に多く左右気管支は左程美 はなく針，ピン等然镍会属異物が大部分であつた。耳異 物以87例で昆虫類が多く稀に中耳炎の合作淀を及る。

5. 異物摘出法は上食道及び受管喉頭直逆镜下の8の が約 75\%で，食道外切開法 5 例（いずれも頸部食道切 開)，気管切開法に上るものが13例あつた。

6. 異物摘出前後の合作症として食道異物に上る自然

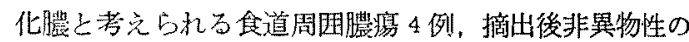
周国膿湯 2 例，死亡 2 例を認めた。気管喉頭異物では特

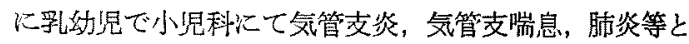
診斨され当利で翼物症であつたものが11 例あつた，気 管翼物死亡例は 3 例であつた。

7. 昭和 7 年より昭和 40 年までの 34 年間，当教室の 異物症の変遗について阪大過去の統計（山川，昭和 7 年 〜䀡和 30年）を参照して検討した。

\section{䓔文献}

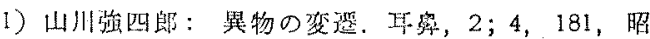
30. 2) 山川強四郎：気道及び食道の異物。第15回 日本医学会総会，東京都，炤34. 3) 佐藤武男ほか： 死の蒜帰を来したシツカロ一ル気道異物症例。耳喉科， $32 ; 2,143$, 昭36.4 4) 任藤武男ほか：最近 5 年間

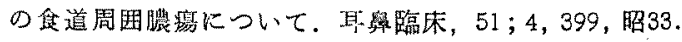

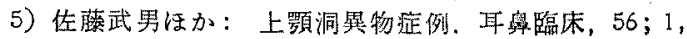

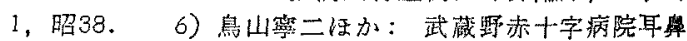

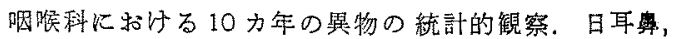
$64 ； 8 ， 1408$ ，炤36.7）市原正堆注か：我教室24年 間の気道並びに食道異物症の統計的観察, 耳胈科, 30; 6,504 , 昭33. 8) 山川強四䬦：耳率咽喉科手術畫. 異物摘出衍，医学萏院，䀡38.9）山川強四郎：日本

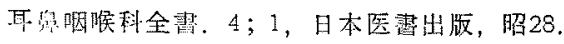

推篗するにあたり御愁切なる御指導，御校閲

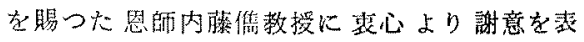
し, 佛せて, 終始御指導を頂いた大阪大学名举 教援山川強四郎，長谷川高敏両先生见梁甚なる 謝意を表します。な括本諭文の要旨は第15回

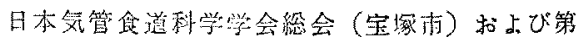
135 回大阪地力会で発琵した。

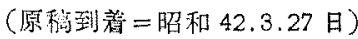

